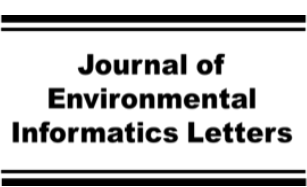

Www.iseis.org/jeil

\title{
Perspective for Emission and Control of Nitrous Gas in Biological Wastewater Treatment
}

\author{
Y. Q. Liu ${ }^{1}$, X. J. Chen ${ }^{1 *}$, H. F. Wang ${ }^{2}$ \\ ${ }^{1}$ Institute for Energy, Environment and Sustainable Communities, 240, 2 Research Drive, Regina, Saskatchewan S4S 7H9, Canada \\ ${ }^{2}$ HSBC Bank Canada, Winnipeg, Manitoba R3P OY4, Canada
}

Received 2 November 2019; revised 29 November 2019; accepted 18 December 2019; published online 31 December 2019

\begin{abstract}
Being the third most significant anthropogenic greenhouse gas, nitrous gas $\left(\mathrm{N}_{2} \mathrm{O}\right)$ has 300 -fold stronger effect than carbon dioxide $\left(\mathrm{CO}_{2}\right)$ and $4 \sim 30$-fold stronger effect than methane $\left(\mathrm{CH}_{4}\right)$. In this study, the main sources and mechanisms of $\mathrm{N}_{2} \mathrm{O}$ emission from biological wastewater treatment were reviewed, and the possible mitigation strategies were discussed. Parameters including dissolved oxygen, temperature, $\mathrm{pH}$, organic carbon, and nitrite concentration have influences on the emission of $\mathrm{N}_{2} \mathrm{O}$. The possible mitigation strategies were put forward by controlling these parameters in biological wastewater treatment and inducing modified technologies such as simultaneous nitrification-denitrification, denitrifying phosphorus removal, and aerobic granular sludge. In order to obtain a near-zero $\mathrm{N}_{2} \mathrm{O}$ emission, applying typical catalysts in the nitrification or denitrification tank to decompose $\mathrm{N}_{2} \mathrm{O}$ into harmless gas is recommended. Moreover, a method of developing photochemical processes to transform $\mathrm{N}_{2} \mathrm{O}$ could also be suggested.
\end{abstract}

Keywords: Nitrous gas, biological wastewater treatment, $\mathrm{N}_{2} \mathrm{O}$ emission mitigation

\section{Introduction}

Greenhouse gas (GHG) emission has received great attention over the past decades (Liu et al., 2018). Typical GHG includes nitrous gas $\left(\mathrm{N}_{2} \mathrm{O}\right)$, carbon dioxide $\left(\mathrm{CO}_{2}\right)$, and methane $\left(\mathrm{CH}_{4}\right)$. Among them, $\mathrm{N}_{2} \mathrm{O}$ has 300-fold stronger effect than $\mathrm{CO}_{2}$ and $4 \sim 30$-fold stronger effect than $\mathrm{CH}_{4}$ (Muthuraman et al., 2019). $\mathrm{N}_{2} \mathrm{O}$ featured in colorless, nonflammable, sweet-smelling is stable in the atmosphere for prolonged periods (Government of Canada, 2017). It has been identified as a significant constituent in several aspects of atmospheric chemistry (Miyahara et al., 2010). Being the third most significant anthropogenic greenhouse gas, $\mathrm{N}_{2} \mathrm{O}$ has been categorized as the greatest contributor to stratospheric ozone depletion (Portmann et al., 2012). The estimated growth of $\mathrm{N}_{2} \mathrm{O}$ emission is expected up to $14.49 \mathrm{Mt} / \mathrm{y}$ by 2020 (Muthuraman et al., 2019).

The industrial sector is regarded as the most significant emission source after agriculture (Liu et al., 2018; Yu et al. 2019), where wastewater treatment is an important resource for $\mathrm{N}_{2} \mathrm{O}$ emission. According to data from Ednhofer et al. (2014), the emission of $\mathrm{N}_{2} \mathrm{O}$ from wastewater treatment accounted for $3.56 \%$ of the total emission load, increasing $20 \%$ compared with the past twenty years. Khalil and Rasmussen (1992) also estimated the global $\mathrm{N}_{2} \mathrm{O}$ emission, putting forward that the annual $\mathrm{N}_{2} \mathrm{O}$ emission rate from sewage was $0.3 \times 10^{12} \sim 3.0 \times$

* Corresponding author. Tel.: +1 3063378537.

E-mail address: chen240x@uregina.ca (X. J. Chen).

ISSN: 2663-6859 print/2663-6867 online

(C) 2019 ISEIS All rights reserved. doi:10.3808/jeil.201900020.
$10^{12} \mathrm{~kg} / \mathrm{y}$, contributing to $3 \% \sim 30 \%$ of total $\mathrm{N}_{2} \mathrm{O}$ emission. Therefore, the emission of $\mathrm{N}_{2} \mathrm{O}$ during wastewater treatment cannot be ignored, and it converts water pollution to air pollution problems, which is opposite to the initial biological design intention to remove nitrogen from wastewater.

Online and continuous monitoring of $\mathrm{N}_{2} \mathrm{O}$ has been employed in recent years for accurate quantification of $\mathrm{N}_{2} \mathrm{O}$ emissions from biological wastewater treatment systems (Sabba et al., 2018). In a biological wastewater treatment plant, $\mathrm{N}_{2} \mathrm{O}$ discharged from an activated sludge pool is usually collected using a closed floating chamber. This technology was originally designed based on a solid surface emission test. During the aeration phase, dissolved $\mathrm{N}_{2} \mathrm{O}$ is stripped from the liquid phase; during the non-aeration phase, fresh air can be added from the bottom of the vessel and the sampled $\mathrm{N}_{2} \mathrm{O}$ can be extracted from the top of the vessel. After the sample of exhausted gas is extracted, the sample can be analyzed by gas chromatograph (Law et al., 2012; Chen et al., 2018).

Studies showed that substantial amount of $\mathrm{N}_{2} \mathrm{O}$ was produced during nitrogen removal process in biological nutrient removal (BNR) plants (Osada et al., 1995). It is reported that about $0.05 \% \sim 25 \%$ of nitrogen is converted to $\mathrm{N}_{2} \mathrm{O}$ in the process of BNR (Vasilaki et al., 2019). There are two biological processes aiming at nitrogen removal: nitrification and denitrification. The main formation of nitrous in wastewater is ammonium, which is converted into nitrite or nitrate during nitrification process. While nitrite is reduced to dinitrogen gas during denitrification process. These two nitrous removal proc- 
esses both lead to the emissions of $\mathrm{N}_{2} \mathrm{O} . \mathrm{N}_{2} \mathrm{O}$ is an intermediate in the heterotrophic denitrification process and is often generated by ammonia-oxidizing bacteria (AOB). In order to complete nitrogen conversion in a limited time, relatively high nitrification and denitrification rates are required, contributing to the emission of $\mathrm{N}_{2} \mathrm{O}$. In addition, bacteria communities change due to the changes of process conditions, which will also affect $\mathrm{N}_{2} \mathrm{O}$ production. The $\mathrm{N}_{2} \mathrm{O}$ emission is also associated with processes of biological wastewater treatment, during which the emission load is various depending on operation parameters (Kampschreur et al., 2009). Therefore, in this study, the main sources and mechanisms of $\mathrm{N}_{2} \mathrm{O}$ emission from biological wastewater treatment were reviewed, and the possible mitigation strategies were discussed.

\section{The Mechanism of $\mathrm{N}_{2} \mathrm{O}$ Emission during Biological Wastewater Treatment}

The BNR processes in biological wastewater treatment produce a large number of GHG such as $\mathrm{CO}_{2}, \mathrm{CH}_{4}$, and $\mathrm{N}_{2} \mathrm{O}$. In this section, the mechanisms of $\mathrm{N}_{2} \mathrm{O}$ production, including nitrification and denitrification are discussed.

\subsection{Nitrification}

In general, during the nitrification process, $\mathrm{NH}_{4}{ }^{+}$or $\mathrm{NH}_{3}{ }^{-}$ is oxidized to $\mathrm{NO}_{3}{ }^{-}$via $\mathrm{NO}_{2}{ }^{-}$. Most of the microorganisms involved in the nitration reaction are obligate autotrophic microorganisms. Nitrification process can be divided into two phases. In the first phase, ammonia-oxidizing bacteria convert $\mathrm{NH}_{4}{ }^{+}$ into $\mathrm{NO}_{2}^{-}$; there are two enzymes that participate in the reaction: ammonia monooxygenase (AMO) and hydroxylamine oxidoreductase (HAO) (Scala and Kerkhof, 1998). In the second phase, $\mathrm{NO}_{2}{ }^{-}$is converted to $\mathrm{NO}_{3}{ }^{-}$by nitrite oxidizing bacteria; the catalytic enzyme is nitrite oxidoreductase (NOR). $\mathrm{N}_{2} \mathrm{O}$ is neither intermediate nor final product throughout the reaction; therefore, $\mathrm{N}_{2} \mathrm{O}$ is a by-product. The complete path is described in Figure 1. The process of biological nitrification is a series of enzymatic reactions. According to Law et al. (2012), the autotrophic AOB usually lack the nitrous oxide reductase gene, which is the root cause of $\mathrm{N}_{2} \mathrm{O}$ production. The enzyme participates in the reaction, but its total amount before and after the reaction does not change. The activity of the enzyme is related to the temperature and the $\mathrm{pH}$ of the environment.

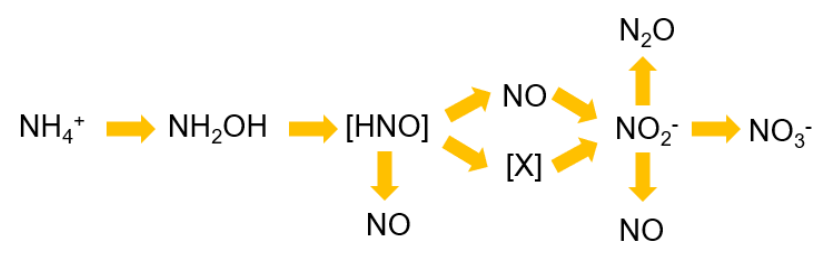

Figure 1. Pathway of nitrification.

\subsection{Denitrification}

Denitrification is a process in which $\mathrm{NO}_{3}^{-}$or $\mathrm{NO}_{2}^{-}$is reduced to $\mathrm{N}_{2} \mathrm{O}$ and $\mathrm{N}_{2}$ by heterotrophic facultative anaerobic microorganisms under anaerobic or hypoxic conditions. Enzymes play a key role in denitrification process, and there are four enzymes involved: nitrate reductase (Nar), nitrite reductase (Nir), nitricoxide reductase (Nor), and nitrous oxidereductase (Nos) (Yu et al., 2010). The complete path is shown in Figure 2. Two modes of nitrate removal can occur in biological processes, including assimilatory and dissimilatory nitrate reduction. Dissimilatory denitrification is responsible for biological denitrification for enhanced nitrogen removal and bacterial cell respiratory electron transport chain for the oxidation of a variety of organic and inorganic substrates.

Compared with the nitrification process, $\mathrm{N}_{2} \mathrm{O}$ is an intermediate substance that is produced during the denitrifycation process. At present, there are two main explanations for the production of $\mathrm{N}_{2} \mathrm{O}$ in the denitrification process. The first one is losing of Nos activity in the denitrifying bacteria. $\mathrm{N}_{2} \mathrm{O}$ generated in the third stage was unable to escape, resulting in $\mathrm{N}_{2} \mathrm{O}$ accumulation from the water (Parton et al., 1996). The second is that part of the denitrifying bacteria does not have a Nos system, and its final product is only $\mathrm{N}_{2} \mathrm{O}$. The amount of $\mathrm{N}_{2} \mathrm{O}$ produced is directly related to the activity of Nar (Parton et al., 1996). Similar with the nitrification process, the activity of the enzyme in denitrification process is determined by factors such as dissolved oxygen, organic carbon sources, and nitrites (Song et al., 2018; Zhang et al., 2019).

$$
\mathrm{N}_{2}-\mathrm{N}_{2} \mathrm{O}-\mathrm{NO}-\mathrm{NO}_{2}^{-}-\mathrm{NO}_{3}^{-}
$$

Figure 2: Pathway of denitrification.

\section{Factors Influencing the Emission of $\mathrm{N}_{2} \mathrm{O}$ in Biological Wastewater Treatment}

The main form of nitrogen in wastewater is ammonia, which can be converted into nitrite or nitrate during nitrification process and thus dinitrogen gas is reduced in denitrification stage. Both nitrification and denitrification processes can lead to the emission of nitrogen oxides (Kampschreur et al., 2009). Figure 3 summarizes the important factors which have significant effects on $\mathrm{N}_{2} \mathrm{O}$ emission. The concentrations of dissolved oxygen (DO) and nitrite play important roles in both nitrification and denitrification processes, and the ratio of chemical oxygen demand/nitrogen (COD/N) affects denitrification process. In this section, the key factors influencing $\mathrm{N}_{2} \mathrm{O}$ emission are reviewed and discussed.

Table 1 illustrates eleven different types of plants including full scale, lab scale, and synthetic biological wastewater treatment plants. The characteristics of wastewater varies among different plants. The full-scale plants are the field plants handling real wastewater such as municipal wastewater treatment plant, factorial wastewater treatment plant, soil stretch wastewater treatment plant and etc. While lab scale and synthetic wastewater treatment plants are designed to obtain some objectives with designed size and operating parameters. In order to investigate major influence factors, the summary of operating parameters is showed in Table 1. 


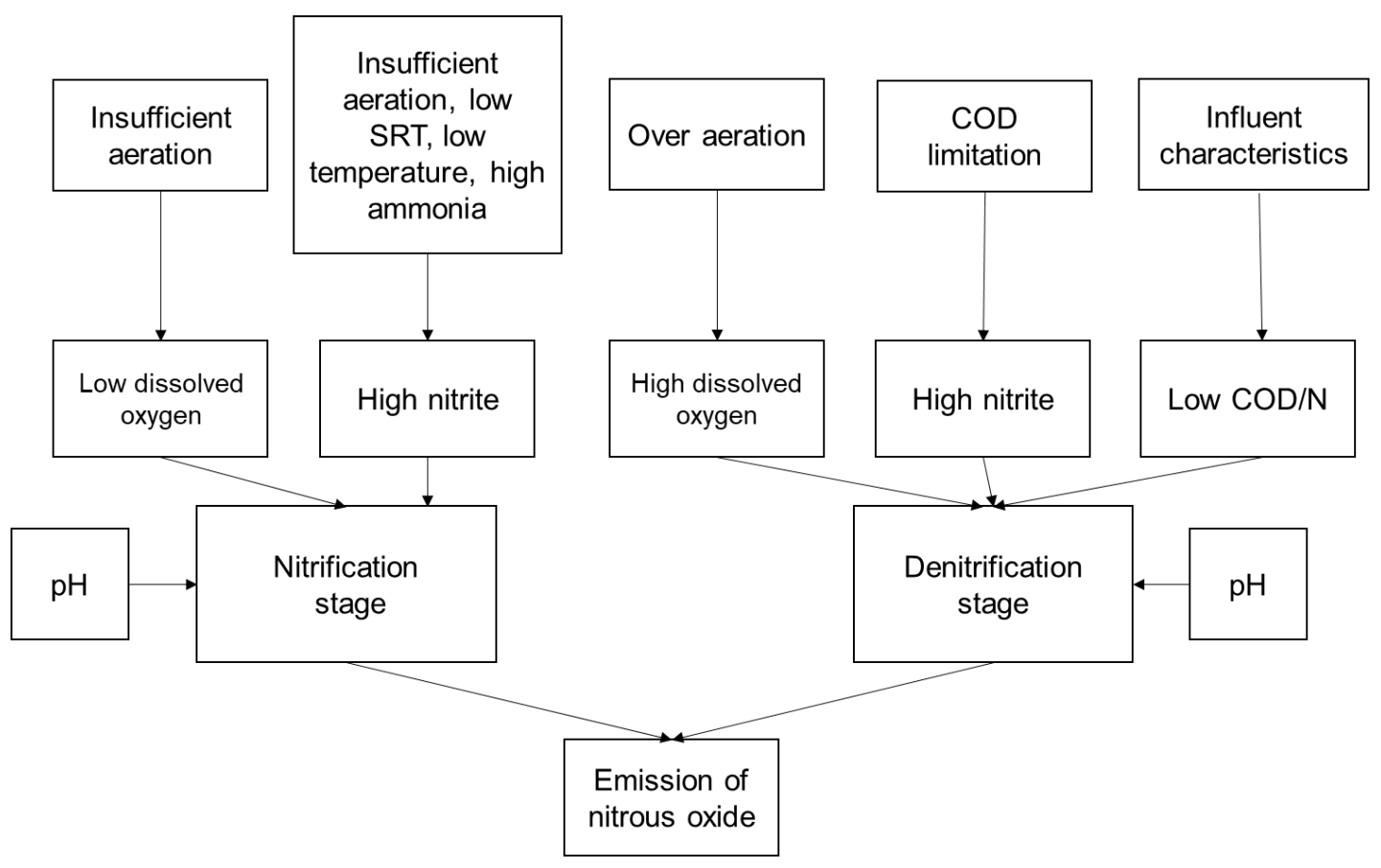

Figure 3. Important factors leading to the $\mathrm{N}_{2} \mathrm{O}$ emission.

\subsection{Dissolved Oxygen}

The $\mathrm{N}_{2} \mathrm{O}$ emission is affected by the concentration of dissolved oxygen in both nitrification and denitrification processes (Kampschreur et al., 2009). During the nitrification process, the ammonia is converted into nitrite by oxidation, in which process $\mathrm{N}_{2} \mathrm{O}$ is produced, followed by the oxidation from nitrite to nitrate. Under the condition of low oxygen, the oxidation rate of nitrite to nitrate is lower than that of ammonia to nitrite. The emission of $\mathrm{N}_{2} \mathrm{O}$ increases with low dissolved oxygen concentration resulting from insufficient aeration (Zeng et al., 2003). The reason for this is that in oxygen-limiting conditions, autotrophic ammonia oxidizers use nitrite as the terminal electron acceptor to save oxygen for the oxygenation reaction of ammonia to hydroxylamine (Kampschreur et al., 2009). As a result, more nitrite is consumed by AOB and ammonium-oxidizing archaea (AOA), leading to the rising of $\mathrm{N}_{2} \mathrm{O}$ emission.

On the other hand, The $\mathrm{N}_{2} \mathrm{O}$ emission is also enhanced in the denitrification process if overload oxygen is provided. The concentration of dissolved oxygen can influence activities of many kinds of dominant enzymes (Tallec et al., 2006). During denitrification, dissolved oxygen can induce $\mathrm{N}_{2} \mathrm{O}$ production by affecting the function of the denitrifying enzyme system, among which the nitrous oxide reductase is more sensitive to dissolved oxygen compared to others. As a result, even a small amount of dissolved oxygen presented will cause the decline of nitrous oxide reductase, leading to the emission of $\mathrm{N}_{2} \mathrm{O}$.

Garrido et al. (1997) did a research and worked out a model to investigate the influence of dissolved oxygen concentration on nitrite accumulation and $\mathrm{N}_{2} \mathrm{O}$ emission in a suspension reactor. The results showed that with the increase of dissolved oxygen concentration, the nitrite concentration increased, reach- ing a peak at about $1.5 \mathrm{mg} / \mathrm{L}$, and then climbed down. There was almost no nitrite when the dissolved oxygen concentration was over $2.5 \mathrm{mg} / \mathrm{L}$. The similar trend was also observed in the nitrite simulation curve. The concentration of nitrate witnessed an upward trend as dissolved oxygen inclined, with a similar trend of simulation data, staying almost stable after $2.5 \mathrm{mg} / \mathrm{L}$ oxygen concentration. In contrast, ammonia decreased as dissolved oxygen rose up. The conclusion was described as that in the low oxygen concentration, nitrite concentration was higher, which resulted in the higher emission of $\mathrm{N}_{2} \mathrm{O}$.

\subsection{Nitrite Concentration}

It is acknowledged that nitrite concentration has a big influence on both nitrification and denitrification processes. Shen et al. (2014) put forward that the emission of $\mathrm{N}_{2} \mathrm{O}$ increased with high nitrite concentration. Peng et al. (2015) did a research and found that $\mathrm{AOB}$ was very sensitive to nitrite. The denitrification of $\mathrm{AOB}$, which was accelerated with increasing concentration of nitrite, caused accumulation of nitrous gas. The reason for this was that the AOB denitrification process was promoted by nitrite reductase Gene nirK and nitric oxide reductase Gene norB mRNA under the condition of high nitrite concentration (Yu and Chandran, 2010).

\subsection{Ammonia Concentration}

The emission of $\mathrm{N}_{2} \mathrm{O}$ increased as increasing ammonia concentration (Ahn et al., 2010). Shen et al. (2014) indicated that one possible reason was that a high nitrifying activity occurred under high ammonium conditions, which might induce high $\mathrm{N}_{2} \mathrm{O}$ emission. According to the results from Shen et 
Table 1. Different Types of Wastewater Treatment Plants and Their Influencing Factors

\begin{tabular}{|c|c|c|c|}
\hline Reference & Type of plant & Main character of wastewater & Main effect factors \\
\hline Czepiel et al. 1995 & $\begin{array}{l}\text { Full-scale municipal wastewater } \\
\text { treatment plant }\end{array}$ & $\begin{array}{l}\text { Influent BOD } 5 \text { at } 20^{\circ} \mathrm{C} \text { of approximately } 250 \\
\mathrm{mg} / \mathrm{L} \text { with an estimated suspended solids } \\
\text { concentration of } 220 \mathrm{mg} / \mathrm{L}\end{array}$ & $\begin{array}{l}\text { Aerated and non-aerated } \\
\text { phases }\end{array}$ \\
\hline $\begin{array}{l}\text { Kampschreur et al. } \\
2008\end{array}$ & $\begin{array}{l}\text { Full scale commercial wastewater } \\
\text { treatment plant }\end{array}$ & Reject water with $\mathrm{TKN}=1265 \pm 41 \mathrm{mg} / \mathrm{L}$ & $\begin{array}{l}\text { Dissolved oxygen, nitrite, } \\
\text { aeration rate, } \mathrm{pH}\end{array}$ \\
\hline $\begin{array}{l}\text { Teiter and Mander, } \\
2005\end{array}$ & $\begin{array}{l}\text { Municipal wastewater treated by } \\
\text { wetlands }\end{array}$ & $\begin{array}{l}\mathrm{BOD}_{7}=96 \mathrm{~g} / \mathrm{m}^{2} ; \text { total } \mathrm{N}=34 \mathrm{~g} / \mathrm{m}^{2} ; \text { total } \mathrm{P}=4.7 \\
\mathrm{~g} / \mathrm{m}^{2}\end{array}$ & $\begin{array}{l}\text { Operation factors of } \\
\text { wetland }\end{array}$ \\
\hline Kong et al. 2002 & Soil-trench wastewater treatment & $\begin{array}{l}\text { Influent of wastewater in Japan: BOD }=252 \\
\mathrm{mg} / \mathrm{L}, \mathrm{TN}=192 \mathrm{mg} / \mathrm{L}, \mathrm{TP}=26 \mathrm{mg} / \mathrm{L} \text {; in China: } \\
\mathrm{BOD}=266 \mathrm{mg} / \mathrm{L}, \mathrm{TN}=87 \mathrm{mg} / \mathrm{L}\end{array}$ & $\begin{array}{l}\text { Structure of the treatment } \\
\text { system }\end{array}$ \\
\hline Tallec et al. 2006 & $\begin{array}{l}\text { Lab scale urban wastewater } \\
\text { treatment plants }\end{array}$ & $\begin{array}{l}1.9 \mathrm{mg} / \mathrm{L} \mathrm{TNK}, 0.1 \mathrm{mg} / \mathrm{L} \text { of } \mathrm{N}-\mathrm{NO}_{2}, 21 \mathrm{mg} / \mathrm{L} \text { of } \\
\mathrm{N}^{-\mathrm{NO}_{3}, 25.9 \mathrm{mg} \mathrm{O}} / 2 / \mathrm{L} \text { of COD, } 2.8 \mathrm{mg} \mathrm{O}_{2} / \mathrm{L} \text { of } \\
\text { BOD }\end{array}$ & $\begin{array}{l}\text { Various conditions of } \\
\text { oxygenation, a gradient of } \\
\text { methanol addition }\end{array}$ \\
\hline Sun et al. 2013 & $\begin{array}{l}\text { Full-scale SBR wastewater } \\
\text { treatment plant }\end{array}$ & $\begin{array}{l}\text { The whole year: } \mathrm{COD}=390 \sim 570 \mathrm{mg} / \mathrm{L} ; \mathrm{TN}= \\
60 \sim 90 \mathrm{mg} / \mathrm{L}\end{array}$ & $\begin{array}{l}\text { DO concentration, water } \\
\text { temperature, influent } \\
\text { COD/N }\end{array}$ \\
\hline Quan et al. 2012 & Laboratory-scale & $\begin{array}{l}\text { Three aeration rates }(0.2,0.6 \text {, and } 1.0 \mathrm{~L} \text { air } / \mathrm{min}) \\
\text { and three } \mathrm{COD} / \mathrm{N} \text { ratios }(1: 0.22,1: 0.15 \text {, and } \\
1: 0.11)\end{array}$ & $\begin{array}{l}\text { Aeration rate and the } \\
\mathrm{COD} / \mathrm{N} \text { ratio }\end{array}$ \\
\hline Shen et al. 2014 & $\begin{array}{l}\text { Lab scale municipal wastewater } \\
\text { treatment plants }\end{array}$ & $\begin{array}{l}510 \mathrm{mg} / \mathrm{L} \text { sodium acetate, } 10 \mathrm{mg} / \mathrm{L} \text { yeast extract, } \\
153 \mathrm{mg} / \mathrm{L} \mathrm{NH} 4 \mathrm{Cl}, 46 \mathrm{mg} / \mathrm{L} \mathrm{Na}_{2} \mathrm{HPO}_{4}, 90 \mathrm{mg} / \mathrm{L} \\
\mathrm{MgSO}_{4} \cdot 7 \mathrm{H}_{2} \mathrm{O}, 14 \mathrm{mg} / \mathrm{L} \mathrm{CaCl}_{2} \cdot 2 \mathrm{H}_{2} \mathrm{O}\end{array}$ & $\begin{array}{l}\text { Different initial ammonium } \\
\text { concentrations; different } \\
\text { initial nitrite concentrations }\end{array}$ \\
\hline $\begin{array}{l}\text { Shiskowski and } \\
\text { Mavinic, } 2006\end{array}$ & Lab scale synthetic wastewater & $\begin{array}{l}\text { Concentration of TOC }=200 \mathrm{mg} \mathrm{C} / \mathrm{L} ; \mathrm{COD}= \\
520 \mathrm{mg} / \mathrm{L} ; \text { organic } \mathrm{N}=12 \mathrm{mg} \mathrm{N} / \mathrm{L}\end{array}$ & $\begin{array}{l}\text { Oxygen, nitrite } \\
\text { concentration, } \mathrm{pH} \\
\text { manipulation }\end{array}$ \\
\hline Adouani et al. 2015 & $\begin{array}{l}\text { Denitrification step in lab scale } \\
\text { wastewater treatment }\end{array}$ & Concentration of $\mathrm{NH}_{4}-\mathrm{N}=6 \mathrm{mg} / \mathrm{L}$ & Temperature \\
\hline Lemaire et al. 2006 & $\begin{array}{l}\text { Lab scale artificial wastewater } \\
\text { treatment }\end{array}$ & $\begin{array}{l}\mathrm{DO}=0.35 \sim 0.5 \mathrm{mg} / \mathrm{L} ; \mathrm{pH}=7.0 \sim 7.5 ; 230 \\
\mathrm{mg} / \mathrm{L} \text { COD as acetate; } 23 \mathrm{mg} / \mathrm{L} \mathrm{NH} 4-\mathrm{N} ; 18 \mathrm{mg} / \mathrm{L} \\
\mathrm{PO}_{4}-\mathrm{P}\end{array}$ & Carbon source \\
\hline
\end{tabular}

al. (2014), it could be observed that the nitrite production rate was increased from 3.30 to $4.78 \mathrm{mg} / \mathrm{g} / \mathrm{h}$ with increasing initial ammonium concentrations from 7.7 to $52.4 \mathrm{mg} / \mathrm{L}$, indicating that nitrite-oxidizing bacteria (NOB) activities might be lowered with increasing ammonium concentrations. The activity of NOB decreased as the concentration of nitrate showing a decreasing trend from 5.65 to $4.5 \mathrm{mg} / \mathrm{g} / \mathrm{h}$. This meant that with increasing of the initial ammonium concentration, the activity of AOB did not change, while that of NOB decreased, which could be due to a higher competition ability of AOB than NOB for oxygen. As a result, $\mathrm{N}_{2} \mathrm{O}$ emission changed from 0.01 to $0.09 \mathrm{mg} / \mathrm{g} / \mathrm{h}$, showing that high $\mathrm{N}_{2} \mathrm{O}$ emission rate occurred with increasing ammonium concentration.

\subsection{Temperature}

The emission of $\mathrm{N}_{2} \mathrm{O}$ is high under the condition of low water temperature (Sun et al., 2013). According to Adouani et al. (2015), the $\mathrm{N}_{2} \mathrm{O}$ emission rate and percentage of $\mathrm{N}_{2} \mathrm{O}$ rose up due to the decrease of temperature. The reason for this was that low temperature slowed down all denitrification enzyme activities and especially $\mathrm{N}_{2} \mathrm{O}$ reductase activities, inducing important emissions of $\mathrm{N}_{2} \mathrm{O}$. In addition, $\mathrm{N}_{2} \mathrm{O}$ reductase could be inhibited by the accumulation of $\mathrm{N}_{2} \mathrm{O}$ in the biological reactor, which explained the accumulation and emission of $\mathrm{N}_{2} \mathrm{O}$, causing a significant pollution transfer to the atmosphere.

\subsection{COD/N Ratio}

During denitrification process, limited organic carbon was observed to increase the emission of $\mathrm{N}_{2} \mathrm{O}$ (Vonschulthess et al., 1995). Quan et al. (2012) investigated the impact of various $\mathrm{COD} / \mathrm{N}$ ratio in synthetic wastewater mixed with pig manure digestate liquid. The studies showed the proportions of $\mathrm{N}_{2} \mathrm{O}$ emission to the influent nitrogen loading rate at the aeration rates at $0.2,0.6$, and $1.0 \mathrm{~L}$ air/min were $8.2,6.1$, and $3.8 \%$ at a COD: $\mathrm{N}$ ratio of $1: 0.22 ; 7.0,5.1$, and $3.5 \%$ at a COD: $\mathrm{N}$ ratio of 1:0.15; and 4.4, 2.9, and $2.2 \%$ at a COD: $\mathrm{N}$ ratio of 1:0.11, respectively. It could be seen that at the same aeration rate, with the decreasing of COD: $\mathrm{N}$ ratio, the proportions of $\mathrm{N}_{2} \mathrm{O}$ emission rose up.

In addition, organic carbon source also plays an important role in the generation of $\mathrm{N}_{2} \mathrm{O}$. The type of microorganisms could be influenced by various carbon sources, resulting in different emission load of $\mathrm{N}_{2} \mathrm{O}$. Studies showed that high $\mathrm{N}_{2} \mathrm{O}$ emission was caused by the low diversity of population due to single carbon source (Lemaire et al., 2006). Addition of an external organic carbon source, methanol, led to an appreciable reduction of the $\mathrm{N}_{2} \mathrm{O}$ emission from 4.5 to $0.2 \%$ of the nitrogen load (Park et al., 2006). The reason for this might be due to the activity of different bacteria which digested carbon source and emitted $\mathrm{N}_{2} \mathrm{O} . \mathrm{N}_{2} \mathrm{O}$ accumulated as soon as organic carbon became limiting and bacteria started to consume internal sto- 
rage compounds (poly-b-hydroxybutyrate) (Kampschreur et al., 2008).

\subsection{Solution pH Level}

The emission of $\mathrm{N}_{2} \mathrm{O}$ is also affected by the $\mathrm{pH}$ level of wastewater. The level of $\mathrm{pH}$ was shown to have a major impact on the $\mathrm{N}_{2} \mathrm{O}$ production rate. Under the condition of investigated $\mathrm{pH}$ range of $6.0 \sim 8.5$, the specific $\mathrm{N}_{2} \mathrm{O}$ production was observed to be the lowest between $\mathrm{pH} 6.0$ and 7.0 at a rate of $0.15 \pm 0.01 \mathrm{mg} \mathrm{N} \mathrm{N}_{2} \mathrm{O}-\mathrm{N} / \mathrm{h} / \mathrm{g}$ volatile suspended solids (VSS). Nevertheless, $\mathrm{N}_{2} \mathrm{O}$ emission rate increased with $\mathrm{pH}$, reaching a maximum rate of $0.53 \pm 0.04 \mathrm{mg} \mathrm{N} 2 \mathrm{O}-\mathrm{N} / \mathrm{h} / \mathrm{g} \mathrm{VSS}$ at $\mathrm{pH}=8.0$. (Law et al., 2011). This result indicated that the tested $\mathrm{pH}$ caused an increase in the $\mathrm{N}_{2} \mathrm{O}$ production rate by promoting the activity of the AOB. Pan et al. (2012) did a similar study and concluded that the maximum $\mathrm{N}_{2} \mathrm{O}$ reduction rate was much more sensitive to $\mathrm{pH}$ variation than nitrate and nitrite reduction rates. The optimal range of $\mathrm{pH}$ was 7.5 to 8.0. It could be summarized that in $\mathrm{pH}$ range of $6.0 \sim 9.0$, the maximum $\mathrm{N}_{2} \mathrm{O}$ reduction rate was strongly influenced by $\mathrm{pH}$, with its value gradually increasing from $\mathrm{pH}=6.0$, reaching its highest level at about $350 \mathrm{mg} \mathrm{N} /(\mathrm{gVSS} \times$ hour$)$ at $\mathrm{pH}=8.0$, followed by a decrease to about $200 \mathrm{mg} \mathrm{N} /(\mathrm{gVSS} \times$ hour $)$ at $\mathrm{pH}=9.0$. A similar trend with respect to $\mathrm{pH}$ changing was witnessed in nitrate and nitrite reduction rates. However, the nitrite and nitrate reduction rates were lower than $\mathrm{N}_{2} \mathrm{O}$ emission rate at the same $\mathrm{pH}$ level. These results suggested that the electrons competition among different nitrogen oxides reductase likely played a role in $\mathrm{N}_{2} \mathrm{O}$ accumulation at low $\mathrm{pH}$ conditions. The affinity of $\mathrm{N}_{2} \mathrm{O}$ reductase with respect to $\mathrm{N}_{2} \mathrm{O}$ decreased as $\mathrm{pH}$ increasing (Pan et al., 2012).

\section{Possible Mitigation Strategies}

$\mathrm{N}_{2} \mathrm{O}$ is a powerful greenhouse gas with a very long lifetime of 150 years and a 320-fold stronger effect than $\mathrm{CO}_{2}$ (Adouani et al., 2015). It is, therefore, necessary to investigate and control the anthropogenic emissions of $\mathrm{N}_{2} \mathrm{O}$. Anthropogenic $\mathrm{N}_{2} \mathrm{O}$ emissions come mainly from energy processes, chemical industries and agriculture and waste treatments. Wastewater treatment is responsible for $3.2 \% \sim 10 \%$ of the total $\mathrm{N}_{2} \mathrm{O}$ emissions (Daelman et al., 2015). Therefore, mitigating the emission of $\mathrm{N}_{2} \mathrm{O}$ in wastewater treatment process is of great need.

\subsection{Control of Operating Parameters}

Dissolved oxygen: As for the concentration of dissolved oxygen, low dissolved oxygen in nitrification process and high dissolved oxygen in denitrification process contribute to increased emission of $\mathrm{N}_{2} \mathrm{O}$. This means that during the nitrification process the supply of oxygen should be sufficient in order to minimize $\mathrm{N}_{2} \mathrm{O}$ emission. Therefore, high aeration can be applied in nitrification process to support sufficient oxygen, inhibiting $\mathrm{N}_{2} \mathrm{O}$ emission (Kampschreur et al., 2008). Some of the biological wastewater treatment plants tend not to apply high aeration due to taking energy consumption into considera- tion. The emitters might consider that increased energy consumption will lead to rising level of carbon dioxide, which is also a dominant greenhouse gas. However, during nitrification process, obtaining enough oxygen is necessary because $\mathrm{N}_{2} \mathrm{O}$ is much more harmful and difficult to handle than $\mathrm{CO}_{2}$.

However, in some cases involving denitrification process such as biofilm-granular sludge systems, high aeration could be practically difficult because increased oxygen concentrations resulted in inhibition of denitrification (Kampschreur et al., 2008). Law et al. (2012) pointed out that the process characteristics of wastewater treatment plants designed and operated for near-complete denitrification contributed to lower and more stable $\mathrm{N}_{2} \mathrm{O}$ generation than the plants with partial denitrification. Therefore, in order to obtain lower $\mathrm{N}_{2} \mathrm{O}$ generation, features concerning in denitrification process employed in wastewater treatment plants should be designed to achieve nearcomplete denitrification. The balance between influent flow and load, low dissolved oxygen concentration, high recycle rate, large bioreactor volume, long solid retention time, and external carbon source dosing are the design features which need to be considered.

Nitrite concentration: Taking nitrite concentration into consideration, high nitrite concentration in both nitrification and denitrification processes will lead to the emissions of $\mathrm{N}_{2} \mathrm{O}$. The factors influencing high nitrite accumulation in nitrification process include insufficient aeration, low solid retention time, low temperature and high ammonia concentration. To control such factors, in full-scale wastewater treatment plants, designing features should be taken into consideration. In detail, loadings are buffered and the risk of transient oxygen depletion is reduced due to the systems equipped with large bioreactor volumes and influent flow-balancing (Law et al., 2012). Similarly, Desloover et al. (2012) also concluded some strategies to reduce accumulation of $\mathrm{NH}_{2} \mathrm{OH}$ and $\mathrm{NO}_{2}{ }^{-}$. The strategies included sufficiently high and constant dissolved oxygen, adapted aeration regime, low free nitrous acid. An end-of-pipe treatment was put forward, which could be supported by the implementation of a newly proposed GHG crediting system. The end of pipe treatment was employed to ensure sufficient copper availability, supporting $\mathrm{N}_{2} \mathrm{O}$ reductase synthesis.

Ratio of COD/N: When it refers to the COD/N, low $\mathrm{N}_{2} \mathrm{O}$ emission could be resulted from high $\mathrm{COD} / \mathrm{N}$ and extra carbon resources. To achieve sufficiently high $\mathrm{COD} / \mathrm{N}$, external COD needs to be provided in the pre-settling stage, and lower COD is able to be removed from sewage. In addition, choosing a proper carbon source is necessary (Desloover et al., 2012). Park et al. (2006) found that the amount of $\mathrm{N}_{2} \mathrm{O}$ produced during wastewater treatment decreased from $4.5 \%$ to $0.2 \%$ of the total $\mathrm{N}$, by introducing methanol as additional carbon source. Shen et al. (2014) used acetate as the initial carbon source, drawing conclusions that with the initial acetate concentration at 250 , 500 , and $1000 \mathrm{mg} / \mathrm{L}$, the concentration of $\mathrm{N}_{2} \mathrm{O}$ emitted at 90 min was $0.75,0.05$, and $0.035 \mathrm{mg} / \mathrm{L}$, respectively. It can be concluded that increasing variety of carbon sources, as well as increasing concentration of carbon sources, is able to achieve low $\mathrm{N}_{2} \mathrm{O}$ emission. 


\subsection{Modified Biological Wastewater Treatment Technology}

Simultaneous nitrification-denitrification technology: Simultaneous nitrification-denitrification (SND) is a modified biological wastewater treatment technology which was developed in recent years (Iannacone et al., 2019). Microbial simultaneous nitrification-denitrification process is the conversion of the ammonium ion to nitrogen gas in a single bioreactor. The process is dependent on flow characteristics, reaction kinetics, mass loading of readily biodegradable chemical oxygen demand (rbCOD) and DO concentration (Liu et al., 2019). It is a new technology for denitrification of wastewater that carries out nitrification and denitrification processes under the same operating conditions in a same reactor. In the SND process, the AOB denitrification, nitrification bacteria nitrification, heterotrophic denitrification, and other processes in the same reactor are performed at the same time. Since $\mathrm{N}_{2} \mathrm{O}$ release may occur in each reaction process, the release characteristics of $\mathrm{N}_{2} \mathrm{O}$ during the SND process are more complicated.

The $\mathrm{N}_{2} \mathrm{O}$ emission in the SND process under hypoxic conditions is an essential product of microbial metabolism. Both heterotrophic denitrifying bacteria and $\mathrm{AOB}$ can produce $\mathrm{N}_{2} \mathrm{O}$, and the denitrification of $\mathrm{AOB}$ is the main reason for $\mathrm{N}_{2} \mathrm{O}$ production (Zhang et al., 2019). Furthermore, denitrification using intracellular polyhydroxyalkanoates (PHAs) as a carbon source increases the amount of generated $\mathrm{N}_{2} \mathrm{O}$ (Yin et al., 2018). However, under high-loading phosphorus conditions, microorganisms can synthesize more PHAs to reduce the denitrifycation enzyme electrons, thereby reducing the amount of $\mathrm{N}_{2} \mathrm{O}$ during heterotrophic denitrification process. In addition, in the SND system, the optimal control of the particle size of the sludge aggregates can achieve $\mathrm{N}_{2} \mathrm{O}$ reduction control (Di Bella and Torregrossa, 2013). By controlling the particle size of the sludge aggregates at 0.45 to $0.9 \mathrm{~mm}$, high nitrification and denitrification activities can be achieved at the same time, thereby reducing $\mathrm{N}_{2} \mathrm{O}$ emissions

Denitrifying ohosphorus removal: Denitrifying phosphorrus removal means that denitrifying phosphate-accumulating bacteria use $\mathrm{NO}_{3}{ }^{-}$or $\mathrm{NO}_{2}{ }^{-}$as electron acceptors under anoxic conditions, and uses internal carbon source PHAs to achieve excess phosphorus absorption in water (Zhou et al., 2010). $\mathrm{N}_{2} \mathrm{O}$ is the main denitrification by-product in this process. The conversion of PHAs plays an important role in the accumulation of $\mathrm{N}_{2} \mathrm{O}$. The reduction of $\mathrm{N}_{2} \mathrm{O}$ is relatively low when using PHAs as a carbon source. In addition, during this process, $\mathrm{NO}_{2}$ or free nitrous acid can inhibit the activity of denitrification enzyme and the absorption of phosphorus, resulting in denitrification efficiency and a large number of $\mathrm{N}_{2} \mathrm{O}$ production.

The production of $\mathrm{N}_{2} \mathrm{O}$ in denitrifying phosphorus removal process mainly occurs in the process of anoxic phosphorus denitrifying and aeration nitrification (Mandel et al., 2019). In the anoxic denitrification stage, continuous water intake and aeration stage can be adopted to reduce $\mathrm{N}_{2} \mathrm{O}$ production by adjusting aeration to prevent nitrification bacteria from denitrifying to avoid $\mathrm{N}_{2} \mathrm{O}$ accumulation. Research found that when continuously adding $\mathrm{NO}_{2}$ and using propionic acid as a carbon source in the denitrifying phosphorus removal process, the electronic competition between denitrifying enzymes can be reduced and $\mathrm{NO}_{2}{ }^{-}$accumulation can be reduced (Jiang et al., 2019). Choosing the right carbon source is beneficial to the reduction of $\mathrm{N}_{2} \mathrm{O}$ in the system. Wang et al. (2014) found that increasing the concentration of influent phosphorus can reduce the formation of $\mathrm{N}_{2} \mathrm{O}$. When the concentration of phosphorus increased from 5 to $50 \mathrm{mg} / \mathrm{L}$, the total $\mathrm{N}_{2} \mathrm{O}$ production decreased from $1.64 \%$ of total nitrogen to $0.16 \%$.

Aerobic granular sludge: The aerobic granular sludge process has good application prospects in wastewater treatment due to its good sedimentation performance and high microbial concentration (Mandel et al., 2019). However, its spatial structure will lead to incomplete denitrification and cause $\mathrm{N}_{2} \mathrm{O}$ production, because the denitrifying and nitrifying bacteria in the particles are difficult to have pure anoxic and aerobic conditions. Temperature can affect $\mathrm{N}_{2} \mathrm{O}$ production by affecting the metabolic activities of functional microbes. Studies from Bao et al. (2018) found that as the temperature increased from 10 to 30 ${ }^{\circ} \mathrm{C}$, the average $\mathrm{N}_{2} \mathrm{O}$ emission factor decreased in the range of $0.15 \% \sim 0.70 \% \mathrm{~N}_{2} \mathrm{O}-\mathrm{N} / \mathrm{NH}_{4}{ }^{+}-\mathrm{N}$ oxidized in the first aeration phase and $0.14 \% \sim 0.15 \% \mathrm{~N}_{2} \mathrm{O}-\mathrm{N} / \mathrm{NH}_{4}{ }^{+}-\mathrm{N}$-oxidized in the second aeration phase. With the increase of temperature, an aerobic environment is more likely to form within the granular sludge. The accumulation of $\mathrm{NO}_{2}{ }^{-}$in the system decreases, contributing to the decrease of $\mathrm{N}_{2} \mathrm{O}$ production.

Other novel methods: Besides controlling operational parameters, some other novel strategies have been developed by researchers. From previous studies, it was learned that microorganisms played an important role in transferring nitrite. Richardson et al. (2009) did a research on enzyme regulation relating to bacteria in denitrification stage. The denitrifying bacteria converted endogenous cytotoxic $\mathrm{NO}$ to $\mathrm{N}_{2} \mathrm{O}$ in order to protect themselves. They could exist in several forms possessing very different enzymatic activities towards $\mathrm{N}_{2} \mathrm{O}$ reduction, which might be caused by changes at the catalytic site $\left[\mathrm{Cu}_{4} \mathrm{~S}\right]$. In order to reduce the generation of $\mathrm{N}_{2} \mathrm{O}$, the genetic expression of the enzyme could be changed on some catalytic sites. Miyahara et al. (2010) studied a new branch of denitrifying bacteria called Pseudomonas stutzeri TR2. It was observed that the strain TR2 produced low levels of $\mathrm{N}_{2} \mathrm{O}$ even under aerobic conditions. After all conditions tested, the strain TR2 was proved to release little levels of $\mathrm{N}_{2} \mathrm{O}$ through exhibiting strong denitrification process. Particularly, when exposed to both $\mathrm{N}_{2} \mathrm{O}$ and nitrite, the strain TR2 bacteria had an affinity of $\mathrm{N}_{2} \mathrm{O}$ as substrate. Consequently, this kind of newly found microorganism has a potential to reduce $\mathrm{N}_{2} \mathrm{O}$ emissions when applied to sewage disposal fields.

\section{Recommendations for Near-Zero Emissions of $\mathrm{N}_{2} \mathrm{O}$ from Biological Wastewater Treatment}

In this study, the parameters influencing $\mathrm{N}_{2} \mathrm{O}$ emission from biological wastewater treatment and the possible mitigation strategies were comprehensively reviewed. During nitrogen removal process, $\mathrm{N}_{2} \mathrm{O}$ was produced due to the nitrifycation and denitrification. Dissolved oxygen, temperature, $\mathrm{pH}$, organic carbon, and other factors affect the release of $\mathrm{N}_{2} \mathrm{O}$. The 
emission of $\mathrm{N}_{2} \mathrm{O}$ can be reduced by controlling influencing parameters in biological wastewater treatment and inducing modified technologies. However, no matter how to adjust the operating parameters and water quality conditions, $\mathrm{N}_{2} \mathrm{O}$ will always be released more or less. Up to now, $\mathrm{N}_{2} \mathrm{O}$ removal technologies in biological wastewater treatment plants were not widely proposed and developed. The reason might be the little contribution to the anthropogenic $\mathrm{N}_{2} \mathrm{O}$ emission budget and the consideration of economic or legislative incentives.

Although the technologies of $\mathrm{N}_{2} \mathrm{O}$ removal in biological wastewater treatment plant are relatively few, some methods concerning $\mathrm{N}_{2} \mathrm{O}$ removal from industrial gases were investigated. The catalytic reduction of $\mathrm{N}_{2} \mathrm{O}$ by $\mathrm{CO}$ molecule over the surface of Si-embedded $\mathrm{MoS}_{2}$ was investigated by Esrafili (2019). The results indicated that the adsorbed $\mathrm{N}_{2} \mathrm{O}$ can be easily decomposed to $\mathrm{N}_{2}$ without activation energy. Fe-ZSM-5 catalysts were used to remove $\mathrm{N}_{2} \mathrm{O}$ from gas by Richards et al. (2018). Comparison of catalysts with relatively high and low Fe loadings achieved comparable levels of $\mathrm{N}_{2} \mathrm{O}$ decomposition when propane is present. The characteristics of catalytic were influenced by $\mathrm{Fe}$ loading and $\mathrm{Si}: \mathrm{Al}$ ratio. In addition, a photochemical process was put forward as an efficient method to remove $\mathrm{N}_{2} \mathrm{O}$, which could be obtained under the condition of atmospheric pressure and room temperature without any catalysts. $\mathrm{N}_{2} \mathrm{O}$ was diluted and decomposed into $\mathrm{N}_{2}, \mathrm{O}_{2}$, and $\mathrm{NO}$ using a $193 \mathrm{~nm}$ ArF excimer laser (Tsuji et al., 2004).

Consequently, a recommendation that applying typical catalysts in the nitrification or denitrification tank to decompose $\mathrm{N}_{2} \mathrm{O}$ into harmless gas is reasonable. Moreover, methods of developing photochemical processes to transform $\mathrm{N}_{2} \mathrm{O}$ can also be considered. Nevertheless, these technologies require a relevantly high cost but the emission of $\mathrm{N}_{2} \mathrm{O}$ accounts for only a little part. Therefore, in the future work, research on $\mathrm{N}_{2} \mathrm{O}$ removal from gas emissions in biological wastewater treatment plant has great potential to mitigate GHG emission.

Acknowledgements. The authors would like to thank Dr. Amornvadee (Amy) Veawab from University of Regina for her support on the topic selection. We would also like to thank the feedbacks from anonymous reviewers whose comments helped improve the quality of this paper.

\section{References}

Abba, S.I., Sinan, J.H., and Abdullahi, J. (2017). River Water Modelling Prediction Using Multi-Linear Regression, Artificial Neural Network, and Adaptive Neuro-Fuzzy Inference System Techniques. Procedia Computer Science, 120, 75-82. https://doi.org/10.1016/j. procs.2017.11.212.

Adouani, N., Limousy, L., Lendormi, and T., Sire, O. (2015). $\mathrm{N}_{2} \mathrm{O}$ and NO emissions during wastewater denitrification step: Influence of temperature on the biological process. Comptes Rendus Chimie, 18(1), 15-22. https://doi.org/10.1016/j.crci.2014.11.005.

Ahn, J.H., Kim, S., Park, H., Rahm, B., Pagilla, K., and Chandran, K. (2010). $\mathrm{N}_{2} \mathrm{O}$ Emissions from Activated Sludge Processes, 20082009: Results of a National Monitoring Survey in the United States. Environmental Science \& Technology, 44(12), 4505-4511. https:// doi.org/10.1021/es903845y.

Bao, Z.Y., Ribera-Guardia, A., Spinelli, M., Sun, D.Z., and Pijuan, M. (2018). The effect of temperature shifts on $\mathrm{N}_{2} \mathrm{O}$ and $\mathrm{NO}$ emissions from a partial nitritation reactor treating reject wastewater. Chemosphere, 212, 162-169. https://doi.org/10.1016/j.chemosphere.2018. 08.090 .

Chen, X.J., Huang, G., An, C.J., Yao, Y., and Zhao, S. (2018). Emerging $\mathrm{N}$-nitrosamines and $\mathrm{N}$-nitramines from amine-based postcombustion $\mathrm{CO}_{2}$ capture-a review. Chemical Engineering Journal, 335, 921-935. https://doi.org/10.1016/j.cej.2017.11.032

Czepiel, P., Crill, P., and Harriss, R. (1995). Nitrous-oxide emissions from municipal waste-water treatment. Environmental Science \& Technology, 29(9), 2352-2356.https://doi.org/10.1021/es00009a030.

Daelman, M.R.J., van Voorthuizen, E.M., van Dongen, U., Volcke, E.I.P., and van Loosdrecht, M.C.M. (2015). Seasonal and diurnal variability of $\mathrm{N}_{2} \mathrm{O}$ emissions from a full-scale municipal wastewater treatment plant. Science of the Total Environment, 536, 1-11. https://doi.org/10.1016/j.scitotenv.2015.06.122.

Desloover, J., Vlaeminck, S.E., Clauwaert, P., Verstraete, W., and Boon, N. (2012). Strategies to mitigate $\mathrm{N}_{2} \mathrm{O}$ emissions from biological nitrogen removal systems. Current Opinion in Biotechnology, 23(3), 474-482. https://doi.org/10.1016/j.copbio.2011.12.030.

Di Bella, G. and Torregrossa, M. (2013). Simultaneous nitrogen and organic carbon removal in aerobic granular sludge reactors operated with high dissolved oxygen concentration. Bioresource Technology, 142, 706-713. https://doi.org/10.1016/j.biortech.2013.05.060.

Esrafili, M.D. (2019). Catalytic reduction of $\mathrm{N}_{2} \mathrm{O}$ over Si-embedded $\mathrm{MoS}_{2}$ monolayer: A single-atom catalyst approach. Inorganic Chemistry Communications, 108, 5. https://doi.org/10.1016/j.inoch e. 2019.107504.

Ednhofer, O., Pichs-madruga, R.I, Sokona, Y., and et al. (2014). Change 2014 Mitigation of climate change. Contribution of working group to the fifth assessment report of the inter-governmental panel on climate change. Cambridge University Press, Cambridge.

Garrido, J.M., vanBenthum, W.A.J., vanLoosdrecht, M.C.M., and Heijnen, J.J. (1997). Influence of dissolved oxygen concentration on nitrite accumulation in a biofilm airlift suspension reactor. Biotechnology and Bioengineering, 53(2), 168-178. https://doi.org /10.1002/(SICI)1097-0290(19970120)53:2<168::AI D-BIT6>3.0.C $\mathrm{O} ; 2-\mathrm{M}$.

Canada, E.A. (2017). Greenhouse gas sources and sinks: Executive summary. https://www.canada.ca/en/environment-climate-change/ services/climate-change/greenhouse-gas-emissions/sources-sinksexecutive-summary.html.

Iannacone, F., Di Capua, F., Granata, F., Gargano, R., Pirozzi, F., and Esposito, G. (2019). Effect of carbon-to-nitrogen ratio on simultaneous nitrification denitrification and phosphorus removal in a microaerobic moving bed biofilm reactor. Journal of Environmental Management, 250, 9. https://doi.org/10.1016/j.jenvman.2019.109 518.

Jiang, C.C., Xu, S.J., Wang, R., Feng, S.G., Zhou, S.N., Wu, S.M., Zeng, X.G., Wu, S.H., Bai, Z.H., Zhuang, G.Q., and Zhuang, X.L. (2019). Achieving efficient nitrogen removal from real sewage via nitrite pathway in a continuous nitrogen removal process by combining free nitrous acid sludge treatment and DO control. Water Research, 161, 590-600. https://doi.org/10.1016/j.watres.2019.06. 040.

Kampschreur, M.J., Temmink, H., Kleerebezem, R., Jetten, M.S.M., and van Loosdrecht, M.C.M. (2009). Nitrous oxide emission during wastewater treatment. Water Research, 43(17), 4093-4103. https:// doi.org/10.1016/j.watres.2009.03.001.

Kampschreur, M.J., van der Star, W.R.L., Wielders, H.A., Mulder, J.W., Jetten, M.S.M., and van Loosdrecht, M.C.M. (2008). Dynamics of nitric oxide and nitrous oxide emission during full-scale reject water treatment. Water Research, 42(3), 812-826. https://doi.org/10.1016/ j.watres.2007.08.022.

Khalil, M.A.K. and Rasmussen, R.A. (1992). The global sources of nitrous oxide. Journal of geophysical research: atmospheres, 97 (D13), 14651-14660. https://doi.org/10.1029/92JD01222 
Kong, H.N., Kimochi, Y., Mizuochi, M., Inamori, R., and Inamori, Y. (2002). Study of the characteristics of $\mathrm{CH}_{4}$ and $\mathrm{N}_{2} \mathrm{O}$ emission and methods of controlling their emission in the soil-trench wastewater treatment process. Science of the Total Environment, 290(1-3), 5967. https://doi.org/10.1016/S0048-9697(01)01058-0.

Law, Y., Lant, P., and Yuan, Z.G. (2011). The effect of pH on $\mathrm{N}_{2} \mathrm{O}$ production under aerobic conditions in a partial nitritation system. Water Research, 45(18), 5934-5944. https://doi.org/10.1016/j.wa tres.2011.08.055

Law, Y., Ni, B.J., Lant, P., and Yuan, Z.G. (2012). $\mathrm{N}_{2} \mathrm{O}$ production rate of an enriched ammonia-oxidising bacteria culture exponentially correlates to its ammonia oxidation rate. Water Research, 46(10), 3409-3419. https://doi.org/10.1016/j.watres.2012.03.043.

Lemaire, R., Meyer, R., Taske, A., Crocetti, G.R., Keller, J., and Yuan, Z.G. (2006). Identifying causes for $\mathrm{N}_{2} \mathrm{O}$ accumulation in a lab-scale sequencing batch reactor performing simultaneous nitrification, denitrification and phosphorus removal. Journal of Biotechnology, 122(1), 62-72. https://doi.org/10.1016/j.jbiotec.2005.08.024.

Liu, L.R., Huang, G.H., Baetz, B., Huang, C.Z., and Zhang, K.Q. (2018). A factorial ecologically-extended input-output model for analyzing urban GHG emissions metabolism system. Journal of cleaner production, 200, 922-933. https://doi.org/10.1016/j.jclepro. 2018.07.298

Liu, L.R., Huang, C.Z., Huang, G.H., Baetz, B., and Pittendrigh, S.M. (2018). How a carbon tax will affect an emission-intensive economy: A case study of the Province of Saskatchewan, Canada. Energy, 159, 817-826. https://doi.org/10.1016/j.energy.2018.06.163.

Liu, W., Nasry, A.A., Zhao, J.Q., Laoyongxay, H., Dai, W., and Zhao, Q. (2019). Start-up of the Simultaneous Nitrification, Anammox, and Denitrification (SNAD) Reactor and Efficacy of a Small Amount of Organic Carbon. Water Air and Soil Pollution, 230(11), 10. https://doi.org/10.1007/s11270-019-4318-3.

Mandel, A., Zekker, I., Jaagura, and M., Tenno, T. (2019). Enhancement of anoxic phosphorus uptake of denitrifying phosphorus removal process by biomass adaption. International Journal of Environmental Science and Technology, 16(10), 5965-5978. https: //doi.org/10.1007/s13762-018-02194-2.

Miyahara, M., Kim, S.W., Fushinobu, S., Takaki, K., Yamada, T., Watanabe, A., Miyauchi, K., Endo, G., Wakagi, T., and Shoun, H. (2010). Potential of Aerobic Denitrification by Pseudomonas stutzeri TR2 to Reduce Nitrous Oxide Emissions from Wastewater Treatment Plants. Applied and Environmental Microbiology, 76(14), 4619-4625. https://doi.org/10.1128/AEM.01983-09.

Muthuraman, G., Ramu, A.G., McAdam, E., and Moon, I.S. (2019). Sustainable removal of $\mathrm{N}_{2} \mathrm{O}$ by mediated electrocatalytic reduction at ambient temperature electro-scrubbing using electrogenerated $\mathrm{Ni}(\mathrm{I})$ electron mediator. Journal of Hazardous Materials, 378, 120765. https://doi.org/10.1016/j.jhazmat.2019.120765.

Osada, T., Kuroda, K., and Yonaga, M. (1995). Reducing nitrous-oxide gas emissions from fill-and-draw type activated-sludge process Water Research, 29(6), 1607-1608. https://doi.org/10.1016/00431354(94)00246-4

Pan, Y.T., Ye, L., Ni, B.J., and Yuan, Z.G. (2012). Effect of pH on $\mathrm{N}_{2} \mathrm{O}$ reduction and accumulation during denitrification by methanol utilizing denitrifiers. Water Research, 46(15), 4832-4840. https:// doi.org/10.1016/j.watres.2012.06.003.

Park, H.D., Wells, G.F., Bae, H., Criddle, C.S., and Francis, C.A. (2006). Occurrence of ammonia-oxidizing archaea in wastewater treatment plant bioreactors. Applied and Environmental Microbiology, 72(8), 5643-5647. https://doi.org/10.1128/AEM.004 02-06.

Parton, W.J., Mosier, A.R., Ojima, D.S., Valentine, D.W., Schimel, D.S., Weier, K., and Kulmala, A.E. (1996). Generalized model for $\mathrm{N}_{2}$ and $\mathrm{N}_{2} \mathrm{O}$ production from nitrification and denitrification. Global Biogeochemical Cycles, 10(3), 401-412. https://doi.org/10.1029/ $96 \mathrm{~GB} 01455$.

Peng, L., Ni, B.J., Ye, L., and Yuan, Z.G. (2015). The combined effect of dissolved oxygen and nitrite on $\mathrm{N}_{2} \mathrm{O}$ production by ammonia oxidizing bacteria in an enriched nitrifying sludge. Water Research, 73, 29-36. https://doi.org/10.1016/j.watres.2015.01.021.

Portmann, R.W., Daniel, J.S., and Ravishankara, A.R. (2012). Stratospheric ozone depletion due to nitrous oxide: influences of other gases. Philosophical Transactions of the Royal Society B: Biological Sciences, 367(1593), 1256-1264. https://doi.org/10.1098/rstb. 2011.0377.

Quan, X.C., Zhang, M.C., Lawlor, P.G., Yang, Z.F., and Zhan, X.M. (2012). Nitrous oxide emission and nutrient removal in aerobic granular sludge sequencing batch reactors. Water Research, 46(16), 4981-4990. https://doi.org/10.1016/j.watres.2012.06.031.

Richards, N., Nowicka, E., Carter, J.H., Morgan, D.J., Dummer, N.F., Golunski, S., and Hutchings, G.J. (2018). Investigating the Influence of Fe Speciation on $\mathrm{N}_{2} \mathrm{O}$ Decomposition over Fe-ZSM-5 Catalysts. Topics in Catalysis, 61(18-19), 1983-1992. https://doi.org/10. 1007/s11244-018-1024-0.

Richardson, D., Felgate, H., Watmough, N., Thomson, A., and Baggs, E. (2009). Mitigating release of the potent greenhouse gas $\mathrm{N}_{2} \mathrm{O}$ from the nitrogen cycle - could enzymic regulation hold the key? Trends in Biotechnology, 27(7), 388-397. https://doi.org/10.1016/j.tibtech. 2009.03.009.

Sabba, F., Terada, A., Wells, G., Smets, B.F., and Nerenberg, R. (2018). Nitrous oxide emissions from biofilm processes for wastewater treatment. Applied Microbiology and Biotechnology, 102(22), 9815 -9829. https://doi.org/10.1007/s00253-018-9332-7.

Scala, D.J. and Kerkhof, L.J. (1998). Nitrous oxide reductase (nosZ) gene-specific PCR primers for detection of denitrifiers and three nosZ genes from marine sediments. Fems Microbiology Letters, 162(1), 61-68. https://doi.org/10.1111/j.1574-6968.1998.tb12979.x.

Shen, L., Guan, Y.T., Wu, G.X., and Zhan, X.M. (2014). N ${ }_{2} \mathrm{O}$ emission from a sequencing batch reactor for biological $\mathrm{N}$ and $\mathrm{P}$ removal from wastewater. Frontiers of Environmental Science \& Engineering, 8(5), 776-783. https://doi.org/10.1007/s11783-013-0586-0.

Shiskowski, D.M. and Mavinic, D.S. (2006). The influence of nitrite and $\mathrm{pH}$ (nitrous acid) on aerobic-phase, autotrophic $\mathrm{N}_{2} \mathrm{O}$ generation in a wastewater treatment bioreactor. Journal of Environmental Engineering and Science, 5(4), 273-283. https://doi.org/10.1139/ s05-034.

Song, P., Huang, G.H., An, C.J., Shen, J., Zhang, P., Chen, X.J., Shen, J., Yao, Y., Zheng, R.B., and Sun, C.X. (2018). Treatment of rural domestic wastewater using multi-soil-layering systems: Performance evaluation, factorial analysis and numerical modeling. Science of the total environment, 644, 536-546. https://doi.org/10. 1016/j.scitotenv.2018.06.331

Sun, S.C., Cheng, X., and Sun, D.Z. 2013. Emission of $\mathrm{N}_{2} \mathrm{O}$ from a full-scale sequencing batch reactor wastewater treatment plant: characteristics \& influencing factors. International Biodeterioration \& Biodegradation, 85, 545-549. https://doi.org/10 1016/j.ibiod.20 13.03.034.

Tallec, G., Garnier, J., and Gousailles, M. (2006). Nitrogen removal in a wastewater treatment plant through biofilters: nitrous oxide emissions during nitrification and denitrification. Bioprocess and Biosystems Engineering, 29(5-6), 323-333. https://doi.org/10.100 7/s00449-006-0081-0.

Teiter, S. and Mander, U. (2005). Emission of $\mathrm{N}_{2} \mathrm{O}, \mathrm{N}_{2}, \mathrm{CH}_{4}$, and $\mathrm{CO}_{2}$ from constructed wetlands for wastewater treatment and from riparian buffer zones. Ecological Engineering, 25(5), 528-541. https://doi.org/10.1016/j.ecoleng.2005.07.011.

Tsuji, M., Kumagae, J., Tsuji, T., and Hamagami, T. (2004). $\mathrm{N}_{2} \mathrm{O}$ removal in $\mathrm{N}_{2}$ or air by $\mathrm{ArF}$ excimer laser photolysis at atmospheric pressure. Journal of Hazardous Materials, 108(3), 189-197. https: //doi.org/10.1016/j.jhazmat.2004.02.024.

Vasilaki, V., Massara, T.M., Stanchev, P., Fatone, F., and Katsou, E. (2019). A decade of nitrous oxide $\left(\mathrm{N}_{2} \mathrm{O}\right)$ monitoring in full-scale wastewater treatment processes: A critical review. Water Research, 
161, 392-412. https://doi.org/10.1016/j.watres.2019.04.022.

Vonschulthess, R., Kuhni, M., and Gujer, W. (1995). Release of nitric and nitrous oxides from denitrifying activated-sludge. Water Research, 29(1), 215-226. https://doi.org/10.1016/0043-1354(94) E01 08-I.

Wang, Y.Y., Zhou, S., Ye, L., Wang, H., Stephenson, T., and Jiang, X.X. (2014). Nitrite survival and nitrous oxide production of denitrifying phosphorus removal sludges in long-term nitrite/nitrate-fed sequencing batch reactors. Water Research, 67, 33-45. https://doi. org/10.1016/j.watres.2014.08.052.

Yin, W.J., Wang, K., Xu, J.T., Wu, D.J., and Zhao, C.C. (2018). The performance and associated mechanisms of carbon transformation (PHAs, polyhydroxyalkanoates) and nitrogen removal for landfill leachate treatment in a sequencing batch biofilm reactor (SBBR). Rsc Advances, 8(74), 42329-42336. https://doi.org/10.1039/C8RA0 7839D.

Yu, L., Li, Y.P., and Huang, G.H. (2019). Planning municipal-scale mixed energy system for stimulating renewable energy under multiple uncertainties-The City of Qingdao in Shandong Province, China. Energy, 166, 1120-1133. https://doi.org/10.1016/j.energy.20 18.10.157

Yu, R. and Chandran, K. (2010). Strategies of Nitrosomonas europaea 19718 to counter low dissolved oxygen and high nitrite concentrations. Bmc Microbiology, 10, 11. https://doi.org/10.118 6/1471-218 0-10-70.
Yu, R., Kampschreur, M.J., van Loosdrecht, M.C.M., and Chandran, K. (2010). Mechanisms and Specific Directionality of Autotrophic Nitrous Oxide and Nitric Oxide Generation during Transient Anoxia. Environmental Science \& Technology, 44(4), 1313-1319. https:// doi.org/10.1021/es902794a.

Zeng, R.J., Lemaire, R., Yuan, Z., and Keller, J. (2003). Simultaneous nitrification, denitrification, and phosphorus removal in a lab-scale sequencing batch reactor. Biotechnology and Bioengineering, 84(2), 170-178.https://doi.org/10.1002/bit.10744.

Zhang, J.L., Li, Y.P., Zeng, X.T., Huang, G.H., Li, Y., Zhu, Y., Kong, F.L., Xi, M., and Liu, J. (2019). Effluent trading planning and its application in water quality management: A factor-interaction perspective. Environmental Research, 168, 286-305. https://doi.org/ 10.1016/j.envres.2018.09.029

Zhang, Z.W., Xu, C.Y., Zhong, D., Han, Y.X., Han, H.J., Zheng, M.Q., and Zhu, H. (2019). Enhanced nitrogen removal of coal pyrolysis wastewater with low COD to nitrogen ratio by partial nitrificationdenitrification bioprocess assisted with polycaprolactone. Environmental Science and Pollution Research, 26(21), 21655-21667. https://doi.org/10.1007/s11356-019-05416-3.

Zhou, S.Q., Zhang, X.J., and Feng, L.Y. (2010). Effect of different types of electron acceptors on the anoxic phosphorus uptake activity of denitrifying phosphorus removing bacteria. Bioresource Technology, 101(6), 1603-1610. https://doi.org/10.1016/j.biortech.2009. 09.032 . 